Emily Conover ${ }^{1}$, Melanie Khamis ${ }^{2 *}$ and Sarah Pearlman ${ }^{3}$

\title{
Gender Imbalances and Labor Market Outcomes: Evidence from Large-Scale Mexican Migration
}

\begin{abstract}
We study the consequences of international migration on labor market outcomes in a developing country. Specifically, we look at the case of Mexico, where large-scale international migration has led to significant declines in the male/female ratio. We explore whether this results in Mexican women entering high-skilled and better paying jobs over time. This question is relevant since there has been an increase in women's education and labor force participation across the developing world, but less evidence of improvements in the gender wage gap. Using an instrumental variables strategy that relies on historical migration patterns, we find that when there are relatively fewer men, women are more likely to work, have high-skilled jobs, and some earn higher wages. These results are robust to the inclusion of state, age group, and year fixed effects, and to different measures of migration and data sources. We explore investments in human capital as a key mechanism. We find that the gains in schooling are concentrated among women with the same average level of education of the men who migrate. From an aggregate perspective, these improvements in job type and wages are important given that higher female income may benefit the status, education, and health of both women and children, which in turn increases a country's development and growth. Our findings are among the few that show some movement toward improvements in the gender wage gap in a developing country setting.
\end{abstract}

\section{Current version: Keywords:}

JEL codes:

Corresponding author:

\section{September 23, 2020}

gender wage gap, female labor force participation, sex ratio, Mexico, migration

J21, J16, J31, 015

Melanie Khamis

mkhamis@wesleyan.edu

\footnotetext{
Department of Economics, Hamilton College, Clinton, NY, USA

2 Department of Economics, Wesleyan University and IZA, Middletown, CT, USA

3 Department of Economics, Vassar College, Poughkeepsie, NY, USA
}

(c) The Author(s). 2021. Open Access This article is distributed under the terms of the Creative Commons Attribution 4.0 International License (http://creativecommons.org/licenses/by/4.0/), which permits unrestricted use, distribution, and reproduction in any medium, provided you give appropriate credit to the original author(s) and the source, provide a link to the Creative Commons license, and indicate if changes were made, @- Cite as: Conover et al. IZA Journal of Development and Migration (2021) 12:02 


\section{Introduction}

We examine the impact of a decline in the ratio of men to women on women's labor market outcomes. We do this for Mexico, where the sex and age imbalance of large-scale international migration has led to a significant decline in the male/female ratio. For example, according to Mexican census data, in the year 2000 the aggregate ratio of men to women 18-25 years old was 0.91 , and for some states it was as low as 0.8 . Given that the natural ratio of men to women is approximately 1:1 (Sen, 1990), this translates into 1-2 fewer men per 10 women than in contexts, such as in the United States or Brazil, with balanced sex ratios (see Figure 1).

The specific question we raise is whether the relative scarcity of men results in Mexican women entering high-skilled and better paying jobs over time. This question is relevant as there has been an increase in women's education and labor force participation across the developing world, but less evidence of improvements in the gender wage gap (Heath and Jayachandran, 2018; Deshpande et al., 2018; Lee and Wie, 2017; Yahmed, 2018). This suggests that the job quality for women has improved more slowly than education, and that occupational change may be key to understand if and when women's labor market outcomes and earnings improve.

Figure 1 Sex ratios. Panel A: By census year and age group, Mexico. Panel B: Comparison of Mexico, United States, and Brazil.

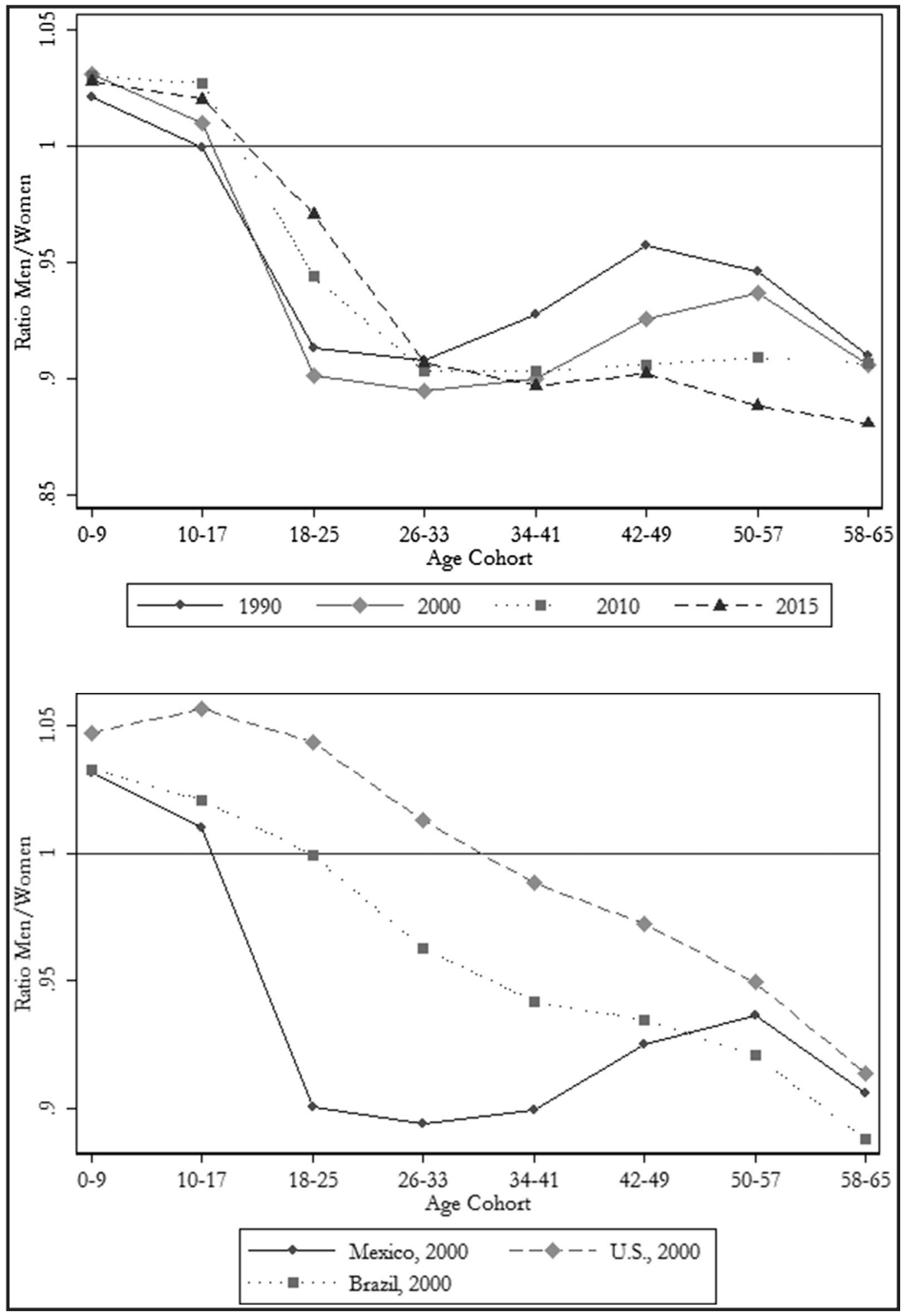

Source: Brazil, Mexican, U.S. Census and ACS, accessed through IPUMS. 
From an aggregate perspective these improvements are important given that higher female income may benefit the status, education, and health of both women and children, which in turn increases their country's development and growth (Duflo, 2012).

We focus on sex ratios as previous literature has found that declining number of men can affect women's schooling and the likelihood of employment, two precursors to changes in job type. In the context of the United States, Acemoglu et al. (2004) found that the large-scale deployment of men in the United States during World War II led to higher female labor force participation after the war, while Goldin $(1991,2006)$ documented the period as a tipping point with continued increases in the labor force participation of women later. Angrist (2002) found that decreases in the relative number of men among specific immigrant groups in the United States led to an increase in labor force participation among women in those same immigrant groups, while Mechoulan (2011) found that high incarceration rates for black men increase education and labor force participation rates for young, black women. More generally, Grossbard and Amuedo-Dorantes (2007) examined differences by region and age cohort due to baby booms and busts and found that lower sex ratios are associated with higher labor force participation rates for women.

There is less evidence on the impact of declining sex ratios on female labor market outcomes in developing countries, despite the fact that many of the drivers of changing sex ratios, such as international migration, wars, and violence, are more prevalent than in developed countries. ${ }^{1}$ A key exception is Raphael (2013) who examined the decline in the relative number of men between 1960 and 2000 in Mexico and found a decline in marriage rates and childbearing, and an increase in educational attainment and labor force participation. While Raphael (2013) focused on marriage markets, we take the next step by examining labor markets and outcomes beyond the likelihood of employment, such as job type, wages, and hours worked. We also use a more recent time period, from 1990 to 2015, when women's labor market participation and education levels are higher. These are important extensions, as there is mixed evidence on what has happened to women's occupations and wages in Mexico. For example, Juhn et al. $(2013,2014)$ found that following trade liberalization in the early 1990 s, female wages and employment improved in blue collar occupations but not in white collar, while Bhalotra et al. (2015) found that the return to "brain"-intensive jobs was higher for women, helping to narrow the gender wage gap at the upper end of the income distribution.

We advance the current literature by providing more evidence of the impact of changes in sex ratios on women's labor market outcomes in a developing country setting and by examining impacts beyond labor force participation. To do this, we use Mexican census and intercensal data from 1990 to 2015. We exploit variation across Mexican states and age groups, and start by documenting the dramatic decline in the sex ratios in Mexico, particularly for younger age groups. We also show that international migration is negatively and significantly related to the sex ratio, and explain a large portion in the variation across states.

In estimating the impact of declining sex ratios on women's labor market outcomes, our main empirical concern is over the endogeneity of sex ratio changes due to local labor demand shocks. ${ }^{2}$ To address potential endogeneity, we use a demand-pull instrument that relies on shocks to demand for Mexican migrant labor from the United States. We exploit the fact that

1 There is a literature on the impact on marriage, fertility, and bargaining power in the household.

2 Here we differ from Raphael (2013) whose main concern is that women with particular marital and fertility preferences may move across states in response to the scarcity of men. He addressed this by using the relative supply of men in the state of birth as an instrument for the relative supply of men in the state of residence. 
the declines in the sex ratio are driven by migration to the United States (more than $90 \%$ of Mexican migrants go to the United States (ENADID, 2009), and their destinations are largely determined by historic patterns and migration networks (Durand et al., 2001; Munshi, 2003). Using three different migration data sources, we document this historical persistence and show that our instrument is a good predictor of sex ratios. We also show that the relationship is not driven by particular sending or receiving states or by our measure of demand for Mexican labor, and it is based only on U.S. locations where historical networks exist.

We find that declines in the relative number of men significantly improve women's labor market outcomes in Mexico. A one standard deviation decline in the sex ratio leads to 3-4 percentage points increase in women's labor force participation, 3-4 percentage points increase of the percentage of working women in white collar jobs, and 5-6 percentage points increase in the percentage in "brain"-intensive jobs. We also find that for some women average wages increase between $3 \%$ and $5 \%$, while the female share in the top $25 \%$ of earners goes up by $1-2$ percentage points. All these results constitute large changes relative to their respective means, and they are robust to different model specifications.

A driving force behind our results is likely human capital attainment. We end by exploring education as a key mechanism through which the absence of men could impact women's labor market outcomes. In the Mexican context high-skilled jobs do not require a college degree, as approximately $60 \%$ of white collar workers have an upper secondary education (12 years) or less. ${ }^{3}$ Since Mexican migrants tend to be young, male, and have an upper secondary education or less (Durand et al., 2001; Chiquiar and Hanson, 2005), this suggests that if women are entering the labor force to replace missing men, they could do so without high levels of education. We find that declining sex ratios significantly increase women's average years of education by approximately 1 year. For many women, this year pushes them to complete lower secondary schooling (9 years), in line with the education profile of migrating men. Results estimated separately for educational attainment levels indicate that women with lower secondary schooling increased their labor force participation, white collar, and "brain" jobs, but did not increase in income. The income gains in the aggregate are driven by college-educated women, suggesting that while less well-educated women move into high-skilled jobs, they do not move into the best paid ones. These results provide recent evidence of a developing country context in which some women have been able to move into better and higher paying jobs over time.

The rest of this article is structured as follows: Section 2 describes the main data sources and shows descriptive statistics; Section 3 discusses our empirical strategy; Section 4 presents the results; Section 5 explores education as a driving mechanism; and Section 6 provides some discussion and concludes.

\section{Data}

The data on sex ratios and labor market outcomes come from the 1990, 2000, and 2010 Mexican Census and the 2015 Mexican Intercensal Survey, all accessed through IPUMS International (Minnesota Population Center 2020). ${ }^{4}$ We use this repeated cross-sectional data to construct

3 See Table A1 in Appendix.

4 We do not use the 1995 Mexican population and dwelling counts, as there is no corresponding U.S. dataset in 1995 for our instrumental variable (the ACS began in 2001). Meanwhile the 2005 intercensal survey does not have information on hours, occupation, or income. 
age group, state, and year level values. For age group, we create five groups for the years in which women are most active in the labor force: ages 18-25, 26-33, 34-41, 42-49, and 50-57. We create these age groups for all 32 Mexican states and census years, yielding a dataset with 640 observations.

Panel A in Figure 1 shows the average sex ratios in Mexico for each of the years in our sample. The figure shows that similar to most countries, the sex ratio for younger age groups (ages 0-9) is over 1, reflecting the slightly higher natural number of male births. The sex ratio declines sharply in the 18-25 age group, where the ratio falls below 1 for all years. It remains below 1 for all remaining age groups and worsens over time for the older age groups. This shows that the problem of "absent men" became more, rather than less, acute over time. These results echo those of other papers, which find that Mexican migration is male dominated in all periods and has become increasingly male over time (Durand et al., 2001; Hanson and McIntosh, 2010; Raphael, 2013).

To show that the lower sex ratios in Mexico are distinctive, we compare them with those from the United States and Brazil using their respective Census data from IPUMS (Minnesota Population Center 2020). We choose Brazil because it is a Latin American country with similar income levels to Mexico. The results, presented in Panel B in Figure 1, confirm that Mexico's trajectory is unique. In the year 2000, in the United States the sex ratio for the 18-25 age group was 1.04, while that for Brazil it was 0.999. For Mexico the ratio was 0.9, which means that relative to the United States or Brazil there was one fewer man for every 10 women in that age group.

\subsection{International migration}

In a simple theoretical framework it can be shown that if internal migration rates are similar for men and women, the sex ratio in any period is a function of the international out and return migration rates for men. ${ }^{5}$ We test these theoretical predictions using census data, which contain information on international migration starting in the year 2000. To measure migration incidence, we use the percentage of households in a state that reports the migration of a household member abroad in the past 5 years. We then regress the sex ratio for each age group on the migration incidence for each state and census year. Panels A and B in Table A2 in the Appendix show a negative and significant relationship between the incidence of international migration and the ratio of men to women in all age groups. For example, the coefficient on international migration incidence in the first column implies that in the year 2000, a one standard deviation increase in the percentage of households with international migrants (3.1 percentage points) is associated with a decline in the ratio of men to women aged 18-25 of 0.04. Furthermore, international migration explains a large percentage of the variation in sex ratios across states. In the year $2000,53 \%$ of the variation in the sex ratios of $18-25$-year-olds and $67 \%$ of the variation in the sex ratios of 26-33-year-olds are explained by international migration.

To further test if international migration explains sex ratio imbalances, we examine the correlation with an alternative cause: homicides. In theory, homicides could be another determinant of changes in sex ratios, as they increased dramatically in Mexico after 2007, were concentrated among young men, and rose in a small number of states (authors' calculations

5 Mexican Census and labor force survey data show similar internal migration rates for men and women. More detail on the theoretical framework, which is similar to that of Raphael (2013), is available upon request. 
using data from the National Institute of Statistics and Geography, INEGI). ${ }^{6}$ However, as shown in Panels C and D in Table A2 in the Appendix, homicides explain little of the variation in sex ratios across states. There is no significant relationship between either homicides per 10,000,000 inhabitants in the year 2010 or total homicides from 2007 to 2010 per 10,000,000 inhabitants and the sex ratio for any age group and the $R^{2}$ values are approximately $1 / 10$ th of the size of those for international migration. This provides further evidence that international migration is unique as a determinant of sex ratios in Mexico.

\subsection{Labor market outcomes}

Summary statistics for the sex ratios and labor market outcomes are shown in Table 1. Here we briefly discuss our outcome variables. Labor force participation is defined as the percentage of women in an age group, state and year which reports having an occupation. ${ }^{7}$ For job type, we consider the percentage of women in the labor force who are employed in jobs defined as

Table 1 Summary statistics

\begin{tabular}{lccccc}
\hline & $\boldsymbol{N}$ & Mean & Standard deviation & Minimum & Maximum \\
\hline Panel A: Explanatory variables of interest & & & & & \\
Sex ratio (men/women) & 640 & 0.93 & 0.05 & 0.81 & 1.13 \\
Predicted migration, EMIF & 640 & 0.21 & 0.17 & 0.01 & 0.95 \\
Predicted migration, ENE & 640 & 0.23 & 0.21 & 0.01 & 1.14 \\
Predicted migration, MC & 640 & 0.21 & 0.17 & 0.01 & 0.84 \\
Predicted migration, historical & 640 & 0.17 & 0.26 & 0.00 & 2.08 \\
\hline Panel B: Labor market outcomes & & & & & \\
Women's labor force participation (\%) & 640 & 0.35 & 0.12 & 0.05 & 0.62 \\
Women in white collar jobs (\%) & 640 & 0.47 & 0.14 & 0.08 & 0.78 \\
Women in "brain" jobs (\%) & 640 & 0.37 & 0.11 & 0.08 & 0.72 \\
Women in male-dominated professions (\%) & 640 & 0.06 & 0.03 & 0.00 & 0.19 \\
Log (average earned monthly income), women & 640 & 7.99 & 0.26 & 7.27 & 8.91 \\
Women in top 25 of income (\%) & 640 & 0.20 & 0.09 & 0.03 & 0.55 \\
Weekly hours worked, for women & 480 & 40.34 & 2.10 & 32.11 & 56.55 \\
\hline Panel C: Other outcomes & & & & & \\
Women in blue collar jobs (\%) & 640 & 0.53 & 0.14 & 0.22 & 0.92 \\
Women in "brawn" jobs (\%) & 640 & 0.63 & 0.11 & 0.28 & 0.89 \\
Years of schooling, women & 640 & 8.00 & 2.43 & 1.57 & 12.98 \\
Lower secondary educated women (\%) & 640 & 0.21 & 0.09 & 0.01 & 0.44 \\
Upper secondary educated women (\%) & 640 & 0.11 & 0.07 & 0.002 & 0.29 \\
College-educated women (\%) & 640 & 0.09 & 0.06 & 0.00 & 0.34 \\
Never married women (\%) & 640 & 0.20 & 0.17 & 0.02 & 0.72 \\
\hline SOurce: Hours worked are avalable & & & & \\
(1) & & & & \\
\end{tabular}

Source: Hours worked are available only in the 1990, 2000, and 2010 census. Income is scaled to 2000 year peso values using CPI information provided by INEGI. See Section 2.2 for details on definition of labor market categories.

6 Data used from INEGI are available in INEGI's website: www.inegi.gob.mx.

7 We choose this over employment status as the coverage is higher. The overlap between the two is high, with over $98 \%$ of those who are employed reporting an occupation. 
white/blue collar, "brain"/“brawn," and "male-dominated" jobs. ${ }^{8}$ Details about how we define each job type are shown in Appendix 1. We also show average education levels by white and blue collar jobs in Table A1 in the Appendix to better understand the education levels that may be required by "high-skilled" jobs. These summary statistics show that while the incidence of college and high-school education is significantly higher for white collar jobs, it is possible to have these jobs with less than either. In this context, "high-skilled" jobs are not limited to those with a college or even a high-school education.

We also look at hours worked and wages, measured by the log of average monthly earned income. ${ }^{9}$ In addition, we consider the percentage of women who fall within the top $25 \%$ of earners for a given state and year. All earned income values are converted to year 2000 pesos using CPI data from INEGI. Hours worked data are available only for the 1990, 2000, and 2010 census, making the sample size for this outcome smaller, with 480 observations.

\section{Empirical strategy}

To estimate the effect of changes in the male-female sex ratio on female labor market outcomes, we use the following specification:

$$
\text { LM Outcome }_{c s t}=\beta_{0}+\beta_{1}\left(\frac{\text { Men }}{\text { Women }}\right)_{c s t}+X_{s t}^{\prime} \gamma+\delta_{c}+\delta_{t}+\delta_{s}+\varepsilon_{c s t}
$$

The dependent variable are measures of labor market outcomes for women in an 8-yearage group $c$, in state $s$, and year $t$. This is modeled as a linear function of the sex ratio, state, year, and age group fixed effects, and industry controls $\left(X_{s t}\right)$, which are the percentage of the state's labor force by census year that is employed in each industry, as defined by two-digit codes. Standard errors are clustered at the state-age group level. If a decline in men relative to women led to increases in women entering the labor market and in certain high-skilled occupations, then we expect $\beta_{1}$ to be negative.

The main concern over the endogeneity of the sex ratio stems from local economic shocks, as negative shocks may incentivize men to leave seeking work elsewhere and may change labor market opportunities for women who remain. ${ }^{10}$ To address this we instrument for the sex ratios using a measure of predicted migration that relies on shocks to the demand for Mexican migrant labor from the United States, the destination for approximately $90 \%$ of Mexican migrants. Specifically, male migration is a function of the supply of labor from Mexico and the demand for Mexican labor in U.S. markets. The supply of labor is likely endogenous to the labor market outcomes of women who stay behind, but the demand for Mexican labor is not, if it is driven by factors that are idiosyncratic to U.S. markets. We thus can use a measure of this demand as an instrument for sex ratios. Key to the feasibility of this demand measure is the fact that Mexican states have historically been sending migrants

8 For example, one data point is the percentage of 18-25-year-old working women in the state of Aguascalientes in 2015 who are in white collar jobs.

9 Income is restricted to those who worked more than zero hours, had nonzero income, and did not have a top-coded income.

10 For example, Hanson and Spilimbergo (1999) found that declines in Mexican wages are associated with increased Mexican migration, while Orrenius and Zavodny (2005) found that worse economic conditions in Mexico increase migration rates, particularly of lower skilled individuals. Meanwhile, Cerrutti and Massey (2001) found that Mexican men are significantly more likely to migrate for employment than women. 
to different locations in the U.S. and labor demand, which varies across these locations. We use this variation to predict sex ratios across Mexican states and time, as we detail as follows.

There also are concerns that the sex ratio could be influenced by women's re-location decisions, if for instance, women with characteristics that impact their labor market outcomes move to states with more (or less) favorable sex ratios. We therefore limit the sample to non-movers, defined as those who reside in their state of birth. This is the closest we can come to eliminating movers, as the census does not include location histories. We test the robustness of our results to this sample restriction in Table A3 in the Appendix.

\subsection{Instrumental variable strategy}

We create the following measure of predicted male migration that was developed by Card (2001):

$$
\text { Predicted male migration }{ }_{c s t}=\frac{\sum_{g=1}^{51} M_{c g t} \lambda_{g s}}{N_{c s t}}
$$

where $M_{c g t}$ is the number of male migrants from Mexico in age group $c$ in U.S. state $g$ and year $t$. The combination of sending Mexican state and U.S. receiving state is determined by $\lambda_{g s}$, or the fraction of Mexicans in the U.S. state $g$ that is from Mexican state $s$. Since the sex ratio should be independent of the size of a Mexican state, we divide the value by $N_{c s t}$ the number of Mexican men in age group $c$, Mexican state $s$, and in year $t$.

To calculate $M_{c g t}$ we use data from $1 \%$ representative micro samples from the U.S. Census and the American Community Survey (ACS), as accessed through IPUMS for 1990, 2000, 2010, and 2015. For each census or ACS year, we calculate the total number of Mexican born men in each age group living in each U.S. state.

To calculate $\lambda_{g s}$, we would ideally have historical migration patterns from a year prior to any of our census periods for all Mexican states going to all receiving states in the United States. However, historical information for the entirety of Mexico and the United States is unavailable. Previous research has documented however that new migrants tend to go to areas where earlier cohorts from the same origin have gone (Bartel, 1989, Conover, 1987). Given the absence of historical comprehensive data and the correlation in migration patterns over time, we therefore rely on data from more recent years to assign Mexican men in each U.S. state to specific states in Mexico. The data we use are obtained from three different sources, as described in Appendix 2.

The instrument captures stocks rather than flows of migrants, predicting the number of Mexican men in an age group living in the United States as of any given year rather than the number who have left over a certain time period. To provide more clarity, we calculate the average predicted male migration to the United States across the states for the year 2000. These means by age group are shown in Table A4 in the Appendix. ${ }^{11}$ The table shows that predicted migration is the highest for the 26-33-year-age group and slowly declines

11 For interpretation, a value of 0.195 , found in the first row in column (1), means that $19.5 \%$ of the men between the ages of 18 and 25 from a given state, on average, are expected to reside in the United States. Approximately $11 \%$ of the total Mexican population is estimated to live abroad. Some reasons why the predicted migration estimates are higher than $11 \%$ are that women, the elderly, and the very young were less likely to migrate during this time period. Furthermore, we use stocks rather than flows of Mexican born men. 
in subsequent age groups. The table also shows consistency across all three weighting data sources, supporting the assertion that migration patterns do not likely change dramatically over time.

\section{Results}

\subsection{First stage regression and robustness checks}

The first stage results are shown in column (1) in Table 2, and are strong. For all three weighting sources, the predicted migration value is negative and significant, showing that higher number of men predicted to be in the United States are associated with lower male-to-female ratios in the sending states in Mexico. Furthermore, as shown in Table 3, the F statistics are well above the threshold level of 10 . Thus predicted migration to the United States is a strong predictor of sex ratios across age groups, states, and years.

The exclusion restriction holds if the predicted number of male migrants is independent of factors that determine women's labor market outcomes that we do not control for. This exogeneity in turn rests on the argument that time invariant weights capture historic trends rather than contemporaneous supply shocks, leading to predicted migration rates that differ from actual ones. Given the unobservable nature of these shocks, we cannot directly test these assumptions. Instead, we provide several indirect tests of whether alternative forms of

Table 2 First stage results

\begin{tabular}{lccccccc}
\hline & $(\mathbf{1})$ & $(\mathbf{2})$ & $\mathbf{( 3 )}$ & $\mathbf{( 4 )}$ & $\mathbf{( 5 )}$ & $\mathbf{( 6 )}$ & $\mathbf{( 7 )}$ \\
\cline { 2 - 7 } & Actual & Random & Excluding & Excluding & Excluding & Excluding & Alternative \\
\cline { 2 - 7 } & Weights & Weights & Strong & Strong & Largest & Largest & Demand \\
\cline { 2 - 7 } & & & Connections & Connections2 & Receiving & Sending & CPS change \\
\hline Predicted & $-0.228^{\star \star \star}$ & $-0.034^{\star \star \star}$ & $-0.295^{\star \star \star}$ & $-0.228^{\star \star \star}$ & $-0.460^{\star \star \star}$ & $-0.301^{\star \star \star}$ & $-0.211^{\star \star \star}$ \\
migration, EMIF & $(0.028)$ & $(0.011)$ & $(0.030)$ & $(0.028)$ & $(0.063)$ & $(0.037)$ & $(0.038)$ \\
$R^{2}$ & 0.61 & 0.57 & 0.62 & 0.61 & 0.59 & 0.61 & 0.55 \\
Predicted & $-0.155^{\star \star \star}$ & $-0.033^{\star \star \star}$ & $-0.175^{\star \star \star}$ & $-0.154^{\star \star \star}$ & $-0.356^{\star \star \star}$ & $-0.194^{\star \star \star}$ & $-0.162^{\star \star \star}$ \\
migration, ENE & $(0.022)$ & $(0.011)$ & $(0.028)$ & $(0.022)$ & $(0.051)$ & $(0.033)$ & $(0.030)$ \\
$R^{2}$ & 0.59 & 0.57 & 0.59 & 0.59 & 0.59 & 0.58 & 0.55 \\
Predicted & $-0.206^{\star \star \star}$ & $-0.033^{\star \star \star}$ & $-0.225^{\star \star \star}$ & $-0.206^{\star \star \star}$ & $-0.360^{\star \star \star}$ & $-0.244^{\star \star \star}$ & $-0.251^{\star \star \star}$ \\
migration, MC & $(0.025)$ & $(0.011)$ & $(0.029)$ & $(0.025)$ & $(0.063)$ & $(0.034)$ & $(0.035)$ \\
$R^{2}$ & 0.60 & 0.57 & 0.60 & 0.60 & 0.58 & 0.59 & 0.56 \\
Observations & 640 & 640 & 640 & 640 & 640 & 600 & 640 \\
\hline
\end{tabular}

Notes: Dependent variable = Sex ratio (men/women). Robust standard errors, clustered at state-age group level in parentheses. All regressions include: state, year, age group fixed effects, percentage of the state's workforce employed in different industries by year (two-digit code). Column (3) excludes connections where both the U.S. and Mexican weights exceed $15 \%$. Column (4) excludes connections where only the U.S. weight exceeds $50 \%$. Column (5) excludes the largest receiving states: California, Texas, Arizona, and Florida. Column (6) excludes main sending states: Michoacán and Zacatecas (immigration rates greater than $10 \%$ of HHs). ${ }^{\star \star \star} p$-value $<0.01,{ }^{* \star} p$-value $<0.05$, ${ }^{*} p$-value $<0.1$.

Source: Mexican Census (MC), accessed through IPUMS. 
Table 3 Second stage IV results

\begin{tabular}{|c|c|c|c|c|c|c|c|}
\hline & (1) & (2) & (3) & (4) & (5) & (6) & (7) \\
\hline & $\begin{array}{c}\text { Female } \\
\text { labor } \\
\text { force } \\
\text { participation }\end{array}$ & $\begin{array}{c}\% \text { Women } \\
\text { in white } \\
\text { collar } \\
\text { jobs }\end{array}$ & $\begin{array}{c}\text { \% Women } \\
\text { in "Brain" } \\
\text { jobs }\end{array}$ & $\begin{array}{l}\text { \% Women } \\
\text { in male- } \\
\text { dominated } \\
\text { professions }\end{array}$ & $\begin{array}{c}\text { Log } \\
\text { monthly } \\
\text { earned } \\
\text { income by } \\
\text { women }\end{array}$ & $\begin{array}{c}\% \text { Women } \\
\text { in top } \\
25 \% \\
\text { income }\end{array}$ & $\begin{array}{c}\text { Weekly } \\
\text { hours } \\
\text { worked } \\
\text { by women }\end{array}$ \\
\hline \multirow{3}{*}{$\begin{array}{l}\text { Sex ratio } \\
\text { (men/women) }\end{array}$} & \multicolumn{7}{|c|}{ Panel A: OLS } \\
\hline & $-0.419^{\star \star \star}$ & $-0.232^{\star \star \star}$ & $-0.457^{\star \star \star}$ & $-0.042^{\star \star}$ & $-0.355^{\star \star \star}$ & -0.063 & -1.241 \\
\hline & $(0.064)$ & $(0.053)$ & $(0.046)$ & $(0.018)$ & $(0.129)$ & $(0.040)$ & $(1.871)$ \\
\hline$R^{2}$ & 0.89 & 0.90 & 0.85 & 0.81 & 0.84 & 0.88 & 0.61 \\
\hline \multirow{3}{*}{$\begin{array}{l}\text { Sex ratio } \\
\text { (men/women) }\end{array}$} & \multicolumn{7}{|c|}{ Panel B: Weighting source EMIF } \\
\hline & $-0.693^{\star \star \star}$ & $-0.676^{\star \star \star}$ & $-1.065^{\star \star \star}$ & -0.020 & $-0.645^{\star \star}$ & -0.125 & $8.865^{\star}$ \\
\hline & $(0.145)$ & $(0.152)$ & $(0.141)$ & $(0.035)$ & $(0.292)$ & $(0.085)$ & $(5.039)$ \\
\hline$R^{2}$ & 0.89 & 0.88 & 0.81 & 0.81 & 0.84 & 0.88 & 0.58 \\
\hline A-P F statistic & 66.12 & 66.12 & 66.12 & 66.12 & 66.12 & 66.12 & 41.60 \\
\hline K-P chi squared & 52.40 & 52.40 & 52.40 & 52.40 & 52.40 & 52.40 & 41.47 \\
\hline \multirow{3}{*}{$\begin{array}{l}\text { Sex ratio } \\
\text { (men/women) }\end{array}$} & \multicolumn{7}{|c|}{ Panel C: Weighting source ENE } \\
\hline & $-0.666^{\star \star \star}$ & $-0.815^{\star \star \star}$ & $-1.167^{\star \star \star}$ & -0.048 & $-1.092^{\star \star}$ & $-0.396^{\star \star \star}$ & $11.499^{\star}$ \\
\hline & $(0.167)$ & $(0.192)$ & $(0.176)$ & $(0.042)$ & $(0.465)$ & $(0.152)$ & $(6.706)$ \\
\hline$R^{2}$ & 0.89 & 0.87 & 0.79 & 0.81 & 0.83 & 0.86 & 0.56 \\
\hline A-P F statistic & 49.09 & 49.09 & 49.09 & 49.09 & 49.09 & 49.09 & 23.15 \\
\hline \multirow[t]{2}{*}{ K-P chi squared } & 35.33 & 35.33 & 35.33 & 35.33 & 35.33 & 35.33 & 20.89 \\
\hline & \multicolumn{7}{|c|}{ Panel D: Weighting Source MC } \\
\hline \multirow{2}{*}{$\begin{array}{l}\text { Sex ratio } \\
\text { (men/women) }\end{array}$} & $-0.822^{\star \star \star}$ & $-0.764^{\star \star \star}$ & $-1.197^{\star \star \star}$ & -0.047 & $-0.871^{\star \star}$ & $-0.244^{\star \star}$ & $13.474^{\star}$ \\
\hline & $(0.155)$ & $(0.173)$ & $(0.172)$ & $(0.039)$ & $(0.358)$ & $(0.103)$ & (7.201) \\
\hline$R^{2}$ & 0.88 & 0.88 & 0.79 & 0.81 & 0.84 & 0.87 & 0.54 \\
\hline A-P F statistic & 65.68 & 65.68 & 65.68 & 65.68 & 65.68 & 65.68 & 32.31 \\
\hline K-P chi squared & 44.19 & 44.19 & 44.19 & 44.19 & 44.19 & 44.19 & 28.70 \\
\hline Observations & 640 & 640 & 640 & 640 & 640 & 640 & 480 \\
\hline
\end{tabular}

Notes: Robust standard errors, clustered at state-age group level in parentheses. All regressions include: state, year, age group fixed effects, percentage of the state's workforce employed in different industries by year (twodigit code). Hours worked are available only in the 1990, 2000, and 2010 census. See Section 2.2 for details on definition of categories. A-P stands for Angrist-Pischke $F$ statistic. K-P stands for Kleinbergen-Paap rk LM chi-squared statistic. ${ }^{\star \star \star} p$-value $<0.01,{ }^{\star \star} p$-value $<0.05,{ }^{\star} p$-value $<0.1$.

Source: Mexican Census, accessed through IPUMS.

the instrument are good predictors of the sex ratio. The goal is to rule out arbitrary potential correlations, which may indicate that our instrument violates the exclusion restriction.

First we examine the assumption that the weighting system reflects historic migrant networks and that it is through these networks that information about demand conditions is received. If this assumption holds, an increase in employment opportunities in U.S. states where men from a given Mexican state historically have not gone should not impact the sex ratio in that Mexican state. To test this, we randomly assign stocks of men between the observed minimum and maximum numbers in U.S. states from the EMIF. We repeat this exercise 1,000 times 
and use the mean value to construct a new instrument. The results are shown in column (2) in Table 2. Although the coefficients remain negative and significant, they are $15 \%$ of the size of those from the original instrument (shown in column (1)). This suggests that male out-migration responds strongly to conditions in U.S. states where there is an established network, but weakly where these networks are negligible.

Second we address concerns that migration networks are so strong that the stock of Mexican men in the receiving U.S. state reflects supply conditions in the sending state. We create a new instrument that removes strong connections, defined as one where the weights for both the sending and receive state exceed 15\% (above the 90th percentile) or where the weights for a sending Mexican state are at or exceed $50 \%$ in any U.S. state. ${ }^{12}$ The results are shown in columns (3) and (4) in Table 2 and produce similar conclusions as our original instrument. This suggests the instrument does not simply capture strong connections.

Third, we address concerns that the first stage is driven by a few receiving states in the United States or a few sending states in Mexico. We remove the largest receiving states in the United States, defined as those in the EMIF where either all or all but one Mexican state has a presence. This removes California, Texas, Arizona, and Florida. These results are shown in column (5) in Table 2. We next remove Mexican states with the highest level of international migration in the year 2000 (the first census where this information was included). We define high migration states as those where more than $10 \%$ of households said they had an international migrant (95th percentile), which removes Michoacán and Zacatecas. The results are shown in column (6) in Table 2. In both cases, the conclusions about the strength of the instrument remain. These confirm that the first stage results are not driven by a small set of states.

Finally, we consider an alternative measure of the demand for Mexican born labor using annual data from the Annual Social and Economic Supplement of the Current Population Survey (CPS), as accessed through IPUMS (Flood et al. 2020). We use changes in the median number of Mexican born and Hispanic men (this includes other Latin American immigrants) in a given age group employed in different U.S. states in 5 years previous to the year in question. ${ }^{13}$ For example, for the year 2000 we calculate the difference between the median number of Mexican born and Hispanic male workers in the 1995-1999 and 1990-1994 periods. The results of the first stage are shown in column (7) in Table 2. The coefficients remain negative and significant, showing that our first stage is robust to using an alternative measure of demand for Mexican male labor.

\subsection{Second stage regressions}

The second stage results are shown in Table 3. Each cell contains the estimated coefficient on the sex ratio for an age group $c$, in state $s$, and year $t$. Standard errors, clustered at the age group-state level, are presented in parentheses. For each outcome, we report second stage IV coefficients for all three weighting sources and OLS coefficients for comparison.

12 In other words, more than 15\% of migrants from a given Mexican state go to a particular U.S. state, and more than 15\% of migrants in that U.S. state are from a particular Mexican state. The double weighting ensures that U.S. states that have small Mexican migrant populations remain.

13 The CPS is not our preferred measure given that it is smaller than the Census and ACS, and does not have sufficient sample size to use only Mexican born men. 
The results show that declines in the number of men to women have strong impacts on the labor market outcomes of women. Starting with labor force participation in column (1), all of the coefficients are negative and significant, with the IV coefficients ranging from -0.666 to -0.822 . This means a one standard deviation decrease in the male-to-female ratio (approximately 0.05 ) results in an increase in women's labor force participation of 3-4 percentage points. Given that a women's labor force participation rate averages $35 \%$, this constitutes an increase in a non-trivial amount of $10-12 \%$.

We also find significant impacts on occupation among women in the labor market. Declines in sex ratios women in the labor force are more likely to be in white collar or "brain" jobs. Specifically, according to the coefficients in column (2), a one standard deviation decrease in the male-to-female ratio leads to an increase in the percentage of women in white collar jobs which ranges from 3 to 4 percentage points (7-9\% of the mean). Results for the percentage of women in "brain" jobs are predicted to increase between $14 \%$ and $16 \%$ of the mean. We therefore find strong evidence that "absent men" increase women's participation in high-skilled jobs.

We also find evidence of gains on earnings. On average, a one standard deviation decline in the ratio of men to women is associated with an increase in log monthly earned income that ranges from 3\% to 5\%. Using ENE and MC migration weights, we note 1-2 percentage points increase (6-10\%) in the percentage of women in the top $25 \%$ of earners. This suggests that the gains from high-skilled jobs might be concentrated at the upper end of the earnings distribution. Finally, for hours worked we find a robust positive coefficient, indicating that as men become relatively scarce, the average number of hours women work in a week falls by $1-2 \%$.

In sum, we find that declines in the number of men relative to women lead to a significant increase in women's labor force participation and their number in high-skilled professions. We also find an increase in average wages likely coming from the top end of the earnings distribution, and a decline in hours worked. These results confirm the findings of Bhalotra et al. (2015), and provide evidence of an environment in which women's labor market outcomes have improved significantly over time.

\subsection{Robustness checks}

In this section, we address concerns that our results might be driven by endogeneity of the instrument. A concern about the Card style instrument is that if economic shocks in the sending locations are correlated over time, weights from the recent past might be correlated with current local economic conditions. We therefore consider weights from an earlier period, when the structure of the economy was different enough from the time period of our study that such correlations are unlikely. We use two sources of historic data that cover a small number of U.S. states to construct these weights. The first data were collected by Foerster (1925) in April 1924 on Mexicans arriving at border ports and at districts in Los Angeles, San Antonio, and El Paso. The second data are a representative sample collected by Taylor on Mexican migrants in different locations in California, Texas, and Illinois (Taylor, 1930 and 1932). The second stage results from an IV model that uses these historic weights are shown in the top panel in Table A3 in the Appendix. Although the instrument is weaker, the coefficients have the same sign as 
those in our original model. This suggests that our results do not simply reflect unobserved economic shocks. ${ }^{14}$

We further address concerns over the extent to which variables in our model control for contemporaneous shocks or preexisting trends determine migration and local labor market outcomes. To do this, we include: (a) state and year trends; (b) state and age group year trends; and (c) foreign direct investment and public expenditure per capita by state and year. These results are shown in the last three panels in Table A3 in the Appendix. The sign and size of the coefficients are such that our main conclusions remain. This provides further evidence that local economic shocks are unlikely to explain our findings. ${ }^{15}$

Finally, we address the concern about potential bias from selective migration, given that we limit the sample to those who reside in their state of birth. We re-estimate the model using the full sample of individuals and present the results in the second panel in Table A3 in the Appendix. Our conclusions remain for all of salient variables, suggesting that selective migration does not drive our findings.

\subsection{Other outcomes}

One question that arises is whether or not women move into any type of job once men leave, or instead move more intensively into high-skilled jobs. To answer this question, we estimate our model using the percentage of women in the labor force in blue collar or "brawn" jobs as outcome variables. These results are shown columns 1 and 2 in Table 4, and the positive coefficients indicate that women are 3-6 percentage points less likely to be employed in either type of job when men are relatively scarce (6-10\% of the mean). The impact of absent men therefore results in women entering high-skilled and higher paying jobs, but not lower skilled ones. ${ }^{16}$

\section{Mechanisms: Human capital accumulation}

One of the main channels through which the absence of men can impact women's labor market outcomes is through human capital accumulation. Human capital accumulation can interact or reinforce other mechanisms that may influence women's ability to get high-skilled and better paid jobs. For instance, as a result of fewer men, women may seek more schooling due to fewer marriage market opportunities (Raphael, 2013); an increase in time since women have less to do in the home (Goldin, 1991); an increase in remittances that provide resources to invest in education (Antman, 2015); and an increase in job vacancies for high-skilled jobs that motivate women to achieve the necessary level of schooling to fill-in these positions. While we cannot investigate each of these channels with our data, we can examine what happens to educational attainment as a result of missing men. We start with total years of schooling. The results shown

14 The correlations between these weights and the EMIF ones for Texas, California, and Illinois are 0.52, 0.24, and 0.45, respectively.

15 We also estimate a model with lagged industry controls. These results, available upon request, are similar to our original ones, providing further evidence that the contemporaneous industry controls are not driving our results.

16 We also estimated the effects of declining sex ratios on men and found that men who stay behind are significantly more likely to enter "brawn" jobs show no evidence of entering white collar jobs and show weak evidence of entering "brain" jobs. Therefore, our results for women do not reflect uniform changes in the composition of low- and high-skilled jobs for men and women. 
Table 4 Other outcomes, second stage, IV results

\begin{tabular}{|c|c|c|c|c|c|c|c|}
\hline & (1) & (2) & (3) & (4) & (5) & (6) & (7) \\
\hline & $\begin{array}{c}\% \text { Female } \\
\text { in blue } \\
\text { collar } \\
\text { jobs }\end{array}$ & $\begin{array}{c}\% \text { Female } \\
\text { in } \\
\text { "Brawn" } \\
\text { jobs }\end{array}$ & $\begin{array}{c}\text { Years of } \\
\text { schooling } \\
\text { for } \\
\text { women }\end{array}$ & $\begin{array}{c}\% \text { Women } \\
\text { with lower } \\
\text { secondary } \\
\text { education } \\
\text { (9) }\end{array}$ & $\begin{array}{c}\text { \% Women } \\
\text { with upper } \\
\text { secondary } \\
\text { education } \\
\text { (12) }\end{array}$ & $\begin{array}{c}\text { \% Women } \\
\text { with } \\
\text { college } \\
\text { education } \\
(16+)\end{array}$ & $\begin{array}{c}\text { \% Women } \\
\text { who } \\
\text { never } \\
\text { married }\end{array}$ \\
\hline \multirow{3}{*}{$\begin{array}{l}\text { Sex ratio } \\
\text { (men/women) }\end{array}$} & \multicolumn{7}{|c|}{ Panel A: OLS } \\
\hline & $0.232^{\star \star \star}$ & $0.460^{\star \star \star}$ & $-6.669^{\star \star \star}$ & $-0.371^{\star \star \star}$ & $0.067^{\star \star}$ & $-0.136^{\star \star \star}$ & 0.033 \\
\hline & $(0.053)$ & $(0.046)$ & $(0.736)$ & $(0.062)$ & $(0.028)$ & $(0.028)$ & $(0.032)$ \\
\hline$R^{2}$ & 0.90 & 0.85 & 0.96 & 0.82 & 0.92 & 0.90 & 0.99 \\
\hline \multirow{3}{*}{$\begin{array}{l}\text { Sex ratio } \\
\text { (men/women) }\end{array}$} & \multicolumn{7}{|c|}{ Panel B: Weighting source EMIF } \\
\hline & $0.676^{\star \star \star}$ & $1.077^{\star \star \star}$ & $-12.733^{\star \star \star}$ & $-0.708^{\star \star \star}$ & $0.381^{\star \star \star}$ & -0.034 & -0.023 \\
\hline & $(0.152)$ & $(0.141)$ & $(1.614)$ & $(0.140)$ & $(0.070)$ & $(0.067)$ & $(0.065)$ \\
\hline \multirow[t]{2}{*}{$R^{2}$} & 0.88 & 0.81 & 0.95 & 0.80 & 0.89 & 0.89 & 0.99 \\
\hline & \multicolumn{7}{|c|}{ Panel C: Weighting source ENE } \\
\hline \multirow{2}{*}{$\begin{array}{l}\text { Sex ratio } \\
\text { (men/women) }\end{array}$} & $0.815^{\star \star \star}$ & $1.168^{\star \star \star}$ & $-17.306^{\star \star \star}$ & $-1.108^{\star \star \star}$ & $0.281^{\star \star \star}$ & -0.109 & 0.063 \\
\hline & $(0.192)$ & $(0.176)$ & $(2.528)$ & $(0.193)$ & $(0.074)$ & $(0.077)$ & $(0.085)$ \\
\hline \multirow[t]{2}{*}{$R^{2}$} & 0.87 & 0.79 & 0.93 & 0.73 & 0.90 & 0.90 & 0.99 \\
\hline & \multicolumn{7}{|c|}{ Panel D: Weighting source MC } \\
\hline \multirow{2}{*}{$\begin{array}{l}\text { Sex ratio } \\
\text { (men/women) }\end{array}$} & $0.763^{\star \star \star}$ & $1.207^{\star \star \star}$ & $-16.072^{\star \star \star}$ & $-0.875^{\star \star \star}$ & $0.303^{\star \star \star}$ & $-0.172^{\star \star \star}$ & 0.006 \\
\hline & $(0.173)$ & $(0.173)$ & (1.965) & $(0.145)$ & $(0.068)$ & $(0.065)$ & $(0.073)$ \\
\hline$R^{2}$ & 0.88 & 0.79 & 0.94 & 0.78 & 0.90 & 0.90 & 0.99 \\
\hline Observations & 640 & 640 & 640 & 640 & 640 & 640 & 640 \\
\hline
\end{tabular}

Notes: Robust standard errors, clustered at state-age group level in parentheses. All regressions include: state, year, age group fixed effects, percentage of the state's workforce employed in different industries by year (two-digit code). ${ }^{\star \star *} p$-value $<0.01,{ }^{\star *} p$-value $<0.05,{ }^{*} p$-value $<0.1$.

Source: Mexican Census, accessed through IPUMS.

in Table 4 indicate that a decline in the sex ratio of one standard deviation (approximately 0.05) leads to an increase in education of $0.6-0.9$ years. Given that women get on average 8 years of education (less than lower secondary school), this constitutes an increase of $8-11 \%$.

The next question is whether an increase in years of schooling falls at key points in the distribution that would push women into educational attainment levels deemed necessary for white collar jobs. To answer this, we examine three different attainment levels: a lower secondary education (9 years of schooling); an upper secondary education (12 years of schooling); or a college education (16 years of more). The results shown in Table 4 indicate that lower secondary school is a key point in the education distribution affected by declining sex ratios. A one standard deviation decrease in the sex ratio leads to an $8-13 \%$ increase in women with a lower secondary education. We also find an indication of some gains for college education, as all the coefficients are negative, but the results are not consistently statistically significant. Meanwhile we find positive coefficients at the upper secondary schooling level, meaning that declining sex ratios lowers the percentage of women with 12 years of schooling. This could be due to some women achieving more education by going on to college, or to some women achieving less education by stopping at lower secondary school. While we cannot rule out the possibility that 
Table 5 Second stage results: by education level

\begin{tabular}{|c|c|c|c|c|c|c|c|}
\hline & (1) & (2) & (3) & (4) & (5) & (6) & (7) \\
\hline & $\begin{array}{c}\text { Female } \\
\text { labor } \\
\text { force } \\
\text { participation }\end{array}$ & $\begin{array}{c}\text { \% Women } \\
\text { in white } \\
\text { collar } \\
\text { jobs }\end{array}$ & $\begin{array}{c}\text { \% Women } \\
\text { in "Brain" } \\
\text { jobs }\end{array}$ & $\begin{array}{c}\text { \% Women } \\
\text { in male- } \\
\text { dominated } \\
\text { professions }\end{array}$ & $\begin{array}{c}\text { Log } \\
\text { monthly } \\
\text { earned } \\
\text { income by } \\
\text { women }\end{array}$ & $\begin{array}{c}\% \text { Women } \\
\text { in top } 25 \% \\
\text { income }\end{array}$ & $\begin{array}{c}\text { Weekly } \\
\text { hours } \\
\text { worked by } \\
\text { women }\end{array}$ \\
\hline & \multicolumn{7}{|c|}{ Panel A: More than upper secondary (>12 years) } \\
\hline \multirow{2}{*}{$\begin{array}{l}\text { Sex ratio } \\
\text { (men/women) }\end{array}$} & $-1.857^{\star}$ & -1.668 & -2.039 & -0.447 & -2.373 & -1.052 & 32.611 \\
\hline & $(0.994)$ & $(1.113)$ & $(1.304)$ & $(0.333)$ & $(1.551)$ & $(0.694)$ & $(49.891)$ \\
\hline$R^{2}$ & -4.47 & -9.08 & -15.96 & -1.51 & -0.77 & -0.87 & -11.02 \\
\hline \multirow[t]{2}{*}{ A-P F statistic } & 3.29 & 2.89 & 2.89 & 2.89 & 2.89 & 2.89 & 0.43 \\
\hline & \multicolumn{7}{|c|}{ Panel B: Upper secondary (10-12 years) } \\
\hline \multirow{2}{*}{$\begin{array}{l}\text { Sex ratio } \\
\text { (men/women) }\end{array}$} & 0.006 & $0.071^{\star}$ & -0.059 & $0.114^{\star \star \star}$ & 0.029 & 0.077 & $-4.924^{\star \star \star}$ \\
\hline & $(0.033)$ & $(0.042)$ & $(0.044)$ & $(0.030)$ & $(0.094)$ & $(0.053)$ & $(1.843)$ \\
\hline$R^{2}$ & 0.66 & 0.68 & 0.85 & 0.32 & 0.79 & 0.76 & 0.28 \\
\hline \multirow[t]{2}{*}{ A-P F statistic } & 22.04 & 22.95 & 22.95 & 22.95 & 22.95 & 22.95 & 17.81 \\
\hline & \multicolumn{7}{|c|}{ Panel C: Lower secondary or less (9 or less) } \\
\hline Sex ratio & $-0.297^{\star \star \star}$ & $-0.235^{\star \star \star}$ & $-0.325^{\star \star \star}$ & $0.046^{\star \star \star}$ & $0.650^{\star \star \star}$ & $0.182^{\star \star \star}$ & $5.324^{\star}$ \\
\hline (men/women) & $(0.065)$ & $(0.081)$ & $(0.060)$ & $(0.011)$ & $(0.186)$ & $(0.039)$ & $(2.912)$ \\
\hline$R^{2}$ & 0.86 & 0.84 & 0.89 & 0.76 & 0.86 & 0.82 & 0.69 \\
\hline A-P F statistic & 56.16 & 56.16 & 56.16 & 56.16 & 56.16 & 56.16 & 29.44 \\
\hline
\end{tabular}

Notes: Robust standard errors, clustered at state-age group level in parentheses. All regressions include the following controls: state, year, age group fixed effects, percentage of the state's workforce employed in different industries by year (two-digit code). Hours worked are available only in the 1990, 2000, and 2010 census. See Section 2.2 for details on definition of labor market categories. A-P stands for Angrist-Pischke $F$ statistic. K-P stands for Kleinbergen-Paap rk LM chi-squared statistic. ${ }^{\star \star *} p$-value $<0.01,{ }^{\star \star} p$-value $<0.05,{ }^{\star} p$-value $<0.1$. Source: Mexican Census, accessed through IPUMS.

some women are leaving school earlier to enter the labor market, the overall increase in years of schooling and the relative magnitude of the coefficients indicate that this is not likely the dominant story.

The results presented in Table 4 indicate that the education channel is operating most strongly on the marginal woman for whom finishing lower secondary school opens job opportunities. The stronger effect on this group is consistent with the average level of schooling for the men who are most likely to migrate. Furthermore, in this study the proportion of women with lower secondary schooling for the time period who have white collar jobs is non-negligible, reaching as much as 27.5\%, as documented in Table A1 in the Appendix. These are likely the women who are driving the employment results.

We investigate if impact of declining sex ratios differs across those with more and less education. Results in Table 5 show that where we saw the most gains in schooling, the lower secondary level (panel C), women have increased their labor force participation and attained white collar and "brain" jobs, but have not increased their wages. This suggests that while these women are moving into high-skilled jobs, they are not moving into the best paid ones. Meanwhile, for college-educated women (panel A) we find evidence of an increase in 
high-skilled jobs and in wages. While the first stage is weak for this group (given this group is the least likely to migrate), these results suggest that the overall gains we see in terms of salary are driven by college-educated women. Finally, for women with more than lower secondary schooling but less than college (between 10 and 12 years), we find little evidence of movement into high-skilled jobs or an improvement in wages. Thus the aggregate gains appear to be driven by women at the lower and higher ends of the educational distribution for high-skilled jobs.

\section{Conclusion}

In this article, we explore the impact of declining ratios of men to women on the labor market outcomes of working age women in Mexico. Unlike other studies in Mexico, we explore outcomes beyond labor market participation, going further in the life cycle of women to look at job type, wages, and hours worked. We examine a more recent period in Mexico (1990-2015), when women's education and labor force participation have increased. These extensions shed light on factors that may change occupations for women, leading to better and higher paying jobs over time.

Overall we find that the decline in the relative number of men significantly improved labor market outcomes for women. We find that women are more likely to enter the labor force and are more likely to have high-skilled jobs once there. For women who achieve lower secondary schooling, we find that increased educational attainment may be a leading explanation for the job results seen. Interestingly, for this level of schooling we find no significant impacts on wages. This suggests that while these women move into high-skilled jobs, they may not be able to move into the highest paid ones. Meanwhile, the aggregate increase in wages that we find appears to be driven by college-educated women.

Despite gains in educational attainment and labor force participation, women have made muted improvements in job type or wages (Blau and Kahn, 2017, Heath and Jayachandran, 2018). Few studies in developing countries have found recent improvements in the gender wage gap (Ahmed and McGillivray, 2015). Recent literature has studied the role of gender norms as one potential explanation. Some of this work focuses on attitudes at the community level (Alesina et al., 2013; Fernández, 2013), while other has looked at intra-household dynamics (Bernhardt et al., 2018). Male migration in Mexico may have contributed to a break in those societal norms that defined the economic roles of women. Women may be observing highskilled job opportunities becoming available and thus preparing themselves for these positions by seeking more education. Future research could explore whether the driving factor in the Mexican context was a change in social norms and exploit the reversal in migration trends to explore whether these changes are short-lived or long lasting.

\section{Declarations}

All dataset used in the analysis are available from:

- IPUMS International (https://international.ipums.org/international/)

- INEGI (https://www.inegi.org.mx/)

- EMIF (https://www.colef.mx/emif/)

None of the authors had competing interests and none received outside funding for this project. 


\section{Acknowledgments}

We thank participants at the World Bank/IZA conference on Labor and Development, the PACDEV, CSAE, NEUDC, and LACEA conferences, AALAC Middlebury conference, UC Berkeley labor lunch, Colgate-Hamilton, Wesleyan, University of Oklahoma, and Rutgers University Economics Seminars. We would also like to thank Randy Akee, David Card, Ira Gang, Daniel Hicks, Rachel Heath, Jenny Hunt, Adriana Kugler, Annemie Maertens, Laura Schechter, Dean Scrimgeour, Chad Sparber, Shing-Yi Wang, Mutlu Yuksel, an anonymous referee and the editor for helpful suggestions and comments. Daniel Kraynak provided excellent research assistance. The code and instructions on how to obtain the data are available upon request.

\section{References}

Acemoglu, Daron; David Lyle; David H. Author (2004): Women, War, and Wages: The Effect of Female Labor Supply on the Wage Structure at Midcentury. Journal of Political Economy 112(3), 497-551.

Ahmed, Salma; Mark McGillivray (2015): Human Capital, Discrimination, and the Gender Wage Gap in Bangladesh. World Development, 67, 506-524.

Alesina, Alberto; Paola Giuliano; Nathan Nunn (2013): On the Origins of Gender Roles: Women and the Plough. The Quarterly Journal of Economics 128(2),469-530.

Angrist, Josh (2002): How Do Sex Ratios Affect Marriage and Labor Markets? Evidence from America's Second Generation. Quarterly Journal of Economics 117(3), 997-1038.

Antman, Francisca M. (2015): Gender Discrimination in the Allocation of Migrant Household Resources. Journal of Population Economics 28(3), 565-592.

Bartel, Ann P. (1989): Where Do the New Us Immigrants Live? Journal of Labor Economics 7(4), 371-391.

Bernhardt, Arielle; Erica Field; Rohini Pande; Natalia Rigol; Simone Schaner; Charity Troyer-Moore (2018): Male Social Status and Women's Work. 108, 363-367.

Bhalotra, Sonia R.; Manuel Fernández; Atheendar S. Venkataramani (2015): The Right Tail and the Right Tale: The Gender Wage Gap in Mexico. Research in Labor Economics 41, 299-341.

Blau, Francine D.; Lawrence M. Kahn (2017): The Gender Wage Gap: Extent, Trends and Explanations. Journal of Economic Literature 55(3), 789-865.

Card, David (2001): Immigrant Inflows, Native Outflows, and the Local Labor Market Impacts of Higher Immigration. Journal of Labor Economics 19(1), 22-64.

Cerrutti, Marcela; Douglas S. Massey (2001): On the Auspices of Female Migration from Mexico to the United States. Demography 38(2), 187-200.

Chiquiar, Daniel; Gordon H. Hanson (2005): International Migration, Self-Selection, and the Distribution of Wages: Evidence from Mexico and the United States. Journal of Political Economy 113(2), 239-281.

Conover, Ted (1987): Coyotes: A Journey Through the Secret World of America's Illegal Aliens. Vintage Books New York.

Deshpande, Ashwini; Deepti Goel; Shantanu Khanna (2018): Bad Karma or Discrimination? Male-Female Wage Gaps Among Salaried Workers in India. World Development 102, 331-344.

Duflo, Esther (2012): Women's Empowerment and Economic Development. Journal of Economic Literature 50(4), 1051-1079.

Durand, Jorge; Douglas S. Massey; Rene M. Zenteno (2001): Mexican Immigration to the United States: Continuities and Changes. Latin American Research Review 36(1), 107-127.

ENADID (2009): INEGI (Instituto Nacional de Estadística y Geografía). Encuesta nacional de la dinámica demográfica. Aguascalientes, Mexico.

Fernández, Raquel (2013): Cultural Change as Learning: The Evolution of Female Labor Force Participation Over A Century. American Economic Review 103(1), 472-500.

Flood, Sarah; Miriam King; Renae Rodgers; Steven Ruggles; J. Robert Warren (2020): Integrated Public Use Microdata Series, Current Population Survey: Version 8.0 [dataset]. Minneapolis, MN: IPUMS. https://doi. org/10.18128/D030.V8.0

Foerster, Robert F. (1925): Report for the Committee on Immigration and Naturalization. Technical Report, Washington.

Goldin, Claudia D. (1991): The Role of World War ii in the Rise of Women's Employment. The American Economic Review 81(4), 741-756.

Goldin, Claudia D. (2006): The Quiet Revolution that Transformed Women's Employment, Education, and Family. The American Economic Review 96(2), 1-21.

Grossbard, Shoshana; Catalina Amuedo-Dorantes (2007): Cohort-Level Sex Ratio Effects on Women's Labor Force Participation. Review of Economics of the Household 5(3), 249-278.

Hanson, Gordon H.; Craig McIntosh (2010): The Great Mexican Emigration. The Review of Economics and Statistics 92(4), 798-810. 
Hanson, Gordon H.; Antonio Spilimbergo. (1999): Illegal Immigration, Border Enforcement, and Relative Wages: Evidence from Apprehensions at the U.S.-Mexico Border. American Economic Review 89(5), 1337-1357.

Heath, Rachel; Seema Jayachandran (2018): The Causes and Consequences of Increased Female Education and Labor Force Participation in Developing Countries, in: Averett, Susan L.; Laura M. Argys; Saul D. Hoffman (eds.), Oxford Handbook of Women and the Economy, New York: Oxford University Press.

Juhn, Chinhui; Gergely Ujhelyi; Carolina Villegas-Sanchez (2013): Trade Liberalization and Gender Inequality. The American Economic Review 103(3), 269-273.

Juhn, Chinhui; Gergely Ujhelyi; Carolina Villegas-Sanchez (2014): Men, Women, and Machines: How Trade Impacts Gender Inequality. Journal of Development Economics 106, 179-193.

Lee, Jong-Wha; Dainn Wie (2017): Wage Structure and Gender Earnings Differentials in China and India. World Development 97, 313-329.

Mechoulan, Stephane (2011): The External Effects of Black Male Incarceration on Black Females. Journal of Labor Economics 29(1), 1-35.

Minnesota Population Center (2020): Integrated Public Use Microdata Series, International: Version 7.3 [dataset]. Minneapolis, MN: IPUMS. https://doi.org/10.18128/D020.V7.2

Munshi, Kaivan (2003): Networks in the Modern Economy: Mexican Migrants in the U.S. Labor Market. Quarterly Journal of Economics 118, 549-599.

Orrenius, Pia M.; Madeline Zavodny (2005): Self-Selection among Undocumented Immigrants from Mexico. Journal of Development Economics 78, 215-240.

Raphael, Steven (2013): International Migration, Sex Ratios, and the Socioeconomic Outcomes of Nonmigrant Mexican Women. Demography 50(3), 971-991.

Rendall, Michelle (2013): Structural Change in Developing Countries: Has it Decreased Gender Inequality? World Development 45, 1-16.

Riosmena, Fernando; Douglas S. Massey (2012): Pathways to El Norte: Origins, Destinations, and Characteristics of Mexican Migrants to the United States. International Migration Review 46(1), 3-36.

Sen, Amartya (1990): More than 100 Million Women Are Missing. New York Review of Books.

Taylor, Paul S. (1930): Mexican Labor in the United States, Volume 1. University of California Publications in Economics, Volume VI.

Taylor, Paul S. (1932): Mexican Labor in the United States, Volume 2. University of California Publications in Economics, Volume III.

Vogl, Tom S. (2014): Height, Skills, and Labor Market Outcomes in Mexico. Journal of Development Economics 107, 84-96.

Yahmed, Sarra Ben (2018): Formal but Less Equal, Gender Wage Gaps in Formal and Informal Jobs in Urban Brazil. World Development 101, 73-97. 


\section{Appendix (For online publication)}

\section{Job Categorization}

\subsection{White Collar Jobs}

We define white collar jobs using the most detailed occupational codes by year. These codes are not standardized by either INEGI or IPUMS across census years, and thus the level of detail ranges from three to four digits (the codes are the same for 1990 and 2000, and different for both 2010 and 2015). Generally we coded as white collar occupations under the following categories: professional, technician, education workers, workers in arts and entertainment (writers, artists not including artisans), directors in the public and private sector, administrative and office workers, and businessmen and sales agents.

Generally we coded as blue collar: professionals sports people; workers in agricultural activities; supervisors, inspectors, and other in artisan or factory manufacture; artisans and factory workers in industries of transformation, repair and maintenance; operators of machinery; helpers, laborers, and other nonqualified workers in the production process; conductors and assistants to conductors of mobile machinery and transportation equipment; lower level office workers; commerce, delivery and dispatchers; traveling salesmen and service workers; workers in services including domestic services; workers in services of protection and guarding, and armed forces.

\section{2 "Brain" Jobs}

"Brain" jobs are defined using one-digit occupational codes (ISCO codes), and they include legislators, senior officials, managers, professionals, technicians, associate professionals, and clerks (ISCO $=1,2,3$, or 4). All other categories, which include service workers, agricultural

Table A1 Average Schooling by Job Type

\begin{tabular}{lccrr}
\hline Year & $\mathbf{1 9 9 0}$ & $\mathbf{2 0 0 0}$ & $\mathbf{2 0 1 0}$ & $\mathbf{2 0 1 5}$ \\
\hline Panel A: Years of education, mean & & & \\
White collar & 15.8 & 13.3 & 12.5 & 12.8 \\
Blue collar & 6.4 & 7.1 & 8.1 & 6.7 \\
\hline Panel B: \% with lower secondary education (9 years) & & \\
White collar & 27.5 & 11.3 & 16.3 & 15.7 \\
Blue collar & 16.1 & 20.1 & 25.9 & 18.0 \\
\hline Panel C: \% with upper secondary education (12 years) & & \\
White collar & 11.1 & 21.4 & 19.6 & 20.4 \\
Blue collar & 4.0 & 9.7 & 12.5 & 8.3 \\
\hline Panel D: \% with college education (16 or more years) & & \\
White collar & 32.9 & 39.1 & 33.6 & 38.1 \\
Blue collar & 3.0 & 3.6 & 4.8 & 3.6 \\
\hline
\end{tabular}

Notes: Values are population weighted averages by census year. See Section 2.2 for details on definition of labor market categories. 
Table A2 Sex Ratios and International Migration

\begin{tabular}{|c|c|c|c|c|c|}
\hline & (1) & (2) & (3) & (4) & (5) \\
\hline \multirow[t]{2}{*}{ Age Groups } & $18-25$ & $26-33$ & $34-41$ & $42-49$ & $50-57$ \\
\hline & \multicolumn{5}{|c|}{ International migration } \\
\hline \multirow{3}{*}{$\% \mathrm{HH}$ with international } & \multicolumn{5}{|c|}{ Panel A: 2000} \\
\hline & $-0.013^{\star \star \star}$ & $-0.014^{\star \star \star}$ & $-0.011^{\star \star \star}$ & $-0.005^{\star}$ & $-0.006^{\star}$ \\
\hline & $(0.002)$ & $(0.002)$ & $(0.002)$ & $(0.003)$ & $(0.003)$ \\
\hline$R^{2}$ & 0.53 & 0.67 & 0.58 & 0.10 & 0.11 \\
\hline \multirow[t]{2}{*}{ Observations } & 32 & 32 & 32 & 32 & 32 \\
\hline & \multicolumn{5}{|c|}{ Panel B: 2010} \\
\hline \multirow[t]{2}{*}{$\% \mathrm{HH}$ with international } & $-0.029^{\star \star \star}$ & $-0.032^{\star \star \star}$ & $-0.019^{\star \star \star}$ & $-0.016^{\star \star \star}$ & $-0.021^{\star \star \star}$ \\
\hline & $(0.005)$ & $(0.006)$ & $(0.005)$ & $(0.005)$ & $(0.007)$ \\
\hline$R^{2}$ & 0.56 & 0.49 & 0.34 & 0.26 & 0.25 \\
\hline \multirow[t]{3}{*}{ Observations } & 32 & 32 & 32 & 32 & 32 \\
\hline & \multicolumn{5}{|c|}{ Homicides } \\
\hline & \multicolumn{5}{|c|}{ Panel C: 2010} \\
\hline \multirow[t]{2}{*}{ Homicides per $10,000,000$} & 0.043 & 0.053 & -0.001 & 0.008 & -0.003 \\
\hline & $(0.032)$ & $(0.039)$ & $(0.029)$ & $(0.028)$ & $(0.037)$ \\
\hline$R^{2}$ & 0.06 & 0.06 & 0.00 & 0.00 & 0.00 \\
\hline \multirow[t]{2}{*}{ Observations } & 32 & 32 & 32 & 32 & 32 \\
\hline & \multicolumn{5}{|c|}{ Panel D: 2007-2010 } \\
\hline \multirow[t]{2}{*}{ Homicides per $10,000,000$} & 0.012 & 0.017 & -0.005 & 0.002 & -0.004 \\
\hline & $(0.012)$ & $(0.015)$ & $(0.011)$ & $(0.011)$ & $(0.014)$ \\
\hline$R^{2}$ & 0.03 & 0.04 & 0.01 & 0.00 & 0.00 \\
\hline Observations & 32 & 32 & 32 & 32 & 32 \\
\hline
\end{tabular}

Notes: Standard errors in parenthesis. ${ }^{\star \star \star} p$-value $<0.01,{ }^{\star \star} p$-value $<0.05,{ }^{\star} p$-value $<0.1$.

Sources: Sex ratios and the percentage of households (HHs) with international migrants are from the Mexican Census, accessed through IPUMS. Homicides are from municipal death records compiled and made available by INEGI.

and fishery workers, crafts and related trade workers and elementary occupations are defined as "brawn." This categorization follows the current literature on brawn-intensive and brainintensive occupations, which a number of authors have employed in the Mexican context (Vogl, 2014, Rendall, 2013, Bhalotra et al., 2015).

\subsection{Male-Dominated Jobs}

These are defined as "brain" occupations in which, as of 1960, more than $75 \%$ of the labor force was male. Specifically, architects, civil engineers, chemical engineers, industrial engineers and similar; chemists and pharmacists; technicians in architecture, engineering, and operators of image and sound recording equipment; professionals in the social sciences; economists, business administrators, public accountants and similar; doctors, orthodontists, and similar; writers, critics, newspaper reporters; painters, sculptors, drawing artists, photographers, choreographers; directors, producers, announcers, and designers of shows and artistic 
Table A3 Second stage results: robustness checks using EMIF weights

\begin{tabular}{|c|c|c|c|c|c|c|c|}
\hline & (1) & (2) & (3) & (4) & (5) & (6) & (7) \\
\hline & $\begin{array}{c}\text { Female } \\
\text { Labor Force } \\
\text { Participation }\end{array}$ & $\begin{array}{c}\% \text { Women } \\
\text { in White } \\
\text { Collar } \\
\text { Jobs }\end{array}$ & $\begin{array}{c}\% \text { Women } \\
\text { in "Brain" } \\
\text { Jobs }\end{array}$ & $\begin{array}{l}\text { \% Women } \\
\text { in Male- } \\
\text { Dominated } \\
\text { Professions }\end{array}$ & $\begin{array}{l}\text { Log } \\
\text { Monthly } \\
\text { Earned } \\
\text { Income by } \\
\text { Women }\end{array}$ & $\begin{array}{l}\% \text { Women } \\
\text { in Top } 25 \% \\
\text { Income }\end{array}$ & $\begin{array}{c}\text { Weekly } \\
\text { Hours } \\
\text { Worked } \\
\text { by Women }\end{array}$ \\
\hline \multirow{3}{*}{$\begin{array}{l}\text { Sex ratio } \\
\text { (men/women) }\end{array}$} & \multicolumn{7}{|c|}{ Panel A: Historic weights } \\
\hline & -0.128 & -1.086 & $-1.111^{\star}$ & -0.199 & $-6.912^{\star \star}$ & $-3.033^{\star \star}$ & 3.215 \\
\hline & $(0.402)$ & $(0.667)$ & $(0.633)$ & $(0.166)$ & $(3.343)$ & $(1.491)$ & $(10.081)$ \\
\hline \multirow[t]{2}{*}{ A-P F statistic } & 6.47 & 6.47 & 6.47 & 6.47 & 6.47 & 6.47 & 7.05 \\
\hline & \multicolumn{7}{|c|}{ Panel B: Movers included } \\
\hline \multirow{2}{*}{$\begin{array}{l}\text { Sex ratio } \\
\text { (men/women) }\end{array}$} & $-0.821^{\star \star \star}$ & $-0.745^{\star \star \star}$ & $-1.122^{\star \star \star}$ & -0.028 & $-0.589^{\star \star}$ & $-0.167^{\star}$ & $9.058^{*}$ \\
\hline & $(0.148)$ & $(0.154)$ & $(0.142)$ & $(0.035)$ & $(0.294)$ & $(0.087)$ & $(4.828)$ \\
\hline \multirow[t]{2}{*}{ A-P F statistic } & 64.23 & 64.23 & 64.23 & 64.23 & 64.23 & 64.23 & 33.69 \\
\hline & \multicolumn{7}{|c|}{ Panel C: State-specific time trend } \\
\hline \multirow{2}{*}{$\begin{array}{l}\text { Sex ratio } \\
\text { (men/women) }\end{array}$} & $-0.714^{\star \star \star}$ & $-0.669^{\star \star \star}$ & $-1.070^{\star \star \star}$ & -0.019 & $-0.680^{\star \star \star}$ & -0.068 & $7.997^{\star \star}$ \\
\hline & $(0.125)$ & $(0.097)$ & $(0.098)$ & $(0.028)$ & $(0.208)$ & $(0.067)$ & $(3.943)$ \\
\hline \multirow[t]{2}{*}{ A-P F statistic } & 58.37 & 58.37 & 58.37 & 58.37 & 58.37 & 58.37 & 41.02 \\
\hline & \multicolumn{7}{|c|}{ Panel D: Age group and state time trends } \\
\hline \multirow{2}{*}{$\begin{array}{l}\text { Sex ratio } \\
\text { (men/women) }\end{array}$} & $1.873^{\star \star \star}$ & $-0.762^{\star \star}$ & $-0.504^{\star}$ & -0.062 & -0.495 & 0.123 & $27.850^{\star \star}$ \\
\hline & $(0.687)$ & $(0.321)$ & $(0.287)$ & $(0.087)$ & $(0.740)$ & $(0.286)$ & $(12.612)$ \\
\hline \multirow[t]{2}{*}{ A-P F statistic } & 6.76 & 6.76 & 6.76 & 6.76 & 6.76 & 6.76 & 7.22 \\
\hline & \multicolumn{7}{|c|}{ Panel E: Additional state-year controls (FDI, Public Expenditure) } \\
\hline \multirow{2}{*}{$\begin{array}{l}\text { Sex ratio } \\
\text { (men/women) }\end{array}$} & $-0.756^{\star \star \star}$ & $-0.671^{\star \star \star}$ & $-1.069^{\star \star \star}$ & -0.033 & $-0.709^{\star \star \star}$ & -0.087 & $6.996^{\star}$ \\
\hline & $(0.123)$ & $(0.097)$ & $(0.098)$ & $(0.026)$ & $(0.206)$ & $(0.065)$ & $(3.940)$ \\
\hline A-P F statistic & 62.77 & 62.77 & 62.77 & 62.77 & 62.77 & 62.77 & 43.21 \\
\hline
\end{tabular}

and cultural programs; upper level government officials; presidents, directors, general managers in institutions and businesses; directors, managers, and area administrators in institutions, businesses and industries; department heads, coordinators, supervisors, administrators and regulation inspectors.

\section{Weighting Data Sources}

The first source we use to calculate our weights, $\lambda_{g s}$, is the EMIF Norte Survey (Encuestas sobre Migración en las Fronteras Norte y Sur de México, or Surveys on Migration to the Northern and Southern borders of Mexico) (EMIF). We thank Anne Le Brun for suggesting this data source. According to EMIF methodology document, 94\% of migrants travel through one of the eight locations. ${ }^{17}$ This dataset collects information on migrants, 15 years old and older, coming from Mexico and in transit to the United States. Migrants are interviewed in locations in the

17 http://www.colef.mx/emif/metodologia/docsmetodologicos/Metodologia\%20Emif\%20Norte\%20y\%20Sur.pdf. 
Table A4 Predicted Male Migration to the United States, year 2000

\begin{tabular}{llccc}
\hline Weighting Source & & EMIF & ENE & MC \\
\cline { 3 - 4 } & & $\mathbf{( 1 )}$ & $\mathbf{( 2 )}$ & $\mathbf{( 3 )}$ \\
\hline 18-25 age group & Mean & 0.195 & 0.213 & 0.195 \\
& Standard deviation & 0.136 & 0.177 & 0.137 \\
26-33 age group & Mean & 0.292 & 0.315 & 0.291 \\
\multirow{3}{*}{ 34-41 age group } & Standard deviation & 0.215 & 0.269 & 0.214 \\
& Mean & 0.280 & 0.306 & 0.282 \\
42-49 age group & Standard deviation & 0.200 & 0.259 & 0.198 \\
\multirow{2}{*}{ 50-57 age group } & Mean & 0.245 & 0.256 & 0.237 \\
& Standard deviation & 0.160 & 0.210 & 0.157 \\
Total & Mean & 0.174 & 0.195 & 0.179 \\
& Standard deviation & 0.113 & 0.163 & 0.113 \\
& Mean & 0.235 & 0.257 & 0.237 \\
\hline
\end{tabular}

Notes: First row number is the mean values across states. The second row number is the standard deviation.

Source: Authors' calculations.

northern Mexican border and at airports during 12 months of the year. Since the majority of migrants are male and we are interested in changes in the sex ratio, we use migration patterns for men. In the survey, migrants are asked the state where they were born, and the US state to which they plan to travel. We use this information to calculate a matrix of migration flows from a particular Mexican state to a particular US state. The data are first collected in 1995 and to abstract from the idiosyncrasies of any given year, we use an aggregate collected in several rounds from 1995 to 2011. We use data from surveys in 1995, 2001, 2002, 2008, and 2011.

The second data source is a module on international migration included in the 2002 National Survey of Employment (ENE), conducted by INEGI. This survey is representative at the state level in Mexico and asks households about members who have migrated abroad in the past 5 years. Members are asked the state in Mexico where the migrant lived before leaving and the specific state in the United States where they arrived. The survey therefore captures migration flows over the 1997-2002 period.

The third data source comes from recently released information from Mexican consulates in the United States on the issuance of identification cards, known as matrículas consulares (MCs) or consular registration card. MCs are issued to individuals living abroad as proof of Mexican citizenship. The cards follow the same security standards as the Mexican passport and can also serve as identification in the United States (Riosmena and Massey, 2012). Mexican consulates began issuing these certificates in 1871 . The data are compiled by the Institute for Mexicans Living Abroad, a government agency. ${ }^{18}$ Both legal and illegal immigrants can apply for them, and it is estimated that $40 \%$ of all Mexicans living in the United States have one. ${ }^{19}$

18 http://www.ime.gob.mx/es/estadisticas-de-mexicanos-en-estados-unidos.

19 Correspondence from Direccion IME Global on July 17, 2014. The data are available on an annual basis from 2008 to the present, and to abstract from the immediate impact of the financial crisis we use data from 2010. 